\title{
How Do The Small, Successful Companies In America Choose Their Auditors?
}

\author{
H. Lon Addams, (Email: LADDAMS@weber.edu), Weber State University
}

Anthony Allred, Weber State University

\section{INTRODUCTION}

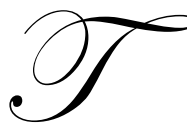

he competition among audit firms is becoming increasingly intense. The pressure to keep clients and gain new clients keeps managing partners on edge. New business is the lifeblood of an audit firm. Furthermore, the publicity surrounding giant companies like Enron, Tyco, WorldCom. et.al., and associated accounting practices has precipitated extra scrutiny of audit firms who present their audit proposals to companies for their business.

In response to corporate scandals in the early 2000s, the Sarbanes-Oxley Act was passed by the legislature and was signed by President Bush within a few weeks of being introduced. This swift action signaled greater accountability in financial statement preparation and verification. Now, audit firms must institute significant strategies to guarantee their operations are sound. Mano, Mouritsen, and Swearingen (2003) contended that the CPA profession is the most important player in the financial well-being of the U.S. Further, they asserted that if financial statements are not truthful, the auditing profession is basically useless.

Another factor has impacted the situation for audit firms in their attempts to acquire new business. Since 911, some firms have tightened their belts; with slimmer budgets they have opted to shrink the size of their audit engagements or not seek an audit at all. In the midst of these market-narrowing events, large audit firms have turned more and more to secure the business of small-but-growing companies.

But, in this highly competitive atmosphere, what sways the decision to retain an accounting firm? Are there several criteria that CEOs use in selecting an audit firm for an engagement with their company? Once a private company chooses an audit firm, what factors contribute to a positive relationship between their company and their accounting firm? Does the retention decision reflect a different set of important factors?

Addams and Allred (2005) surveyed the Inc. 500-the small, fastest-growing companies in America- as identified by Inc. Magazine. The researchers asked the CEOs of these Inc. 500 companies to rate various factors used to select an auditor (see Table 1). In a separate, earlier study Addams and Allred (2002) queried the CEOs of the Inc. 500, using a similar list of selection factors (see Table 2). However, because of the extensive publicity, lawsuits, and finger-pointing surrounding the demise of many previously respected companies- now accused of deception and "unconventional accounting practices"- ethical reputation has become perhaps the quintessential issue of the day for accounting firms and auditors and those companies that hire them. Hence, the purpose of this study is to compare and contrast the results of the aforementioned two studies to determine whether CEOs' perceptions of the important factors related to hiring audit firms may have changed. If so, what are the implications for managers and strategies for the future.

\section{BACKGROUND}

Past research studies have set out to determine the most important factor(s) regarding the selection of audit firms. For example, Abbott and Parker (2001) found that companies with independent and active audit committees were more likely to view industry specialization by an auditor as enhancing audit quality. A study by Woo and Koh (2001) provide some support to the belief that auditor changes are more likely in cases where firms change their management composition, experience a lower diffusion of ownership,_experience an increase in income manipulation opportunities, have many subsidiaries, or have more rapid growth. 
A few studies have researched this interesting dilemma from slightly differing angles. Addams and Davis (1992) surveyed the managing partners of the large national audit firms and found that their perception was that the audit fee was the key factor in selection decisions. In 1996, Gregory and Collier studied the relationship of fees and change regarding auditor selection. In a 1994 study, Hermanson et. al. found that reputation was the most important criterion in the selection of an accounting firm with personnel next in importance. Fee consideration was more important to small clients. The study by Hermanson was limited to auditing clients of large national accounting firms.

Stanny, Anderson, and Nowak (2000) surveyed 1,224 clients of a single, local accounting firm in the San Francisco Bay area. The researchers found that personal integrity of the accountant, technical and industry expertise, returning of phone calls, size of the firm, partner personalities, recommendations by others, and cost of services were the most important factors in the initial selection. It should be noted, however, that this study focused on one particular accounting firm and its array of clients in a single geographical area--San Francisco, which limits the ability to generalize the results of the study.

\section{METHODOLOGY}

Addams and Allred (2002), in an attempt to better understand the auditor selection process, surveyed the CEOs of the Inc. Magazine 500 (Inc. 500). Since many audit firms are incorporating strategies that attempt to increase the number of audits of small firms, the study focused its attention on the small, successful companies in the U.S. Each year, Inc. Magazine selects their "Inc. 500"; these top 500 small firms are selected by Inc. Magazine on the basis of profitability, sales revenue gains, number of employees, and so on. For a company to be listed in Inc. 500 a company must have been independent and privately held at the time of the selection.

In the 2002 study, the Inc. 500 CEOs responded to a list questions regarding the selection of an independent audit firm. The CEOs rated the importance (scale: six equaled great importance and 0 equaled no importance) of the following: technical expertise, personal relationships, industry expertise, proposed fee, oral presentation, location, referral, size, key employees, and international services provided (see Table 2). In 2005, Addams and Allred again surveyed Inc. 500 CEOs. The study used the 2002 list of questions, but added the highly relevant factor "ethical reputation of the firm." See Table 1. This study attempts to compare and contrast the previous studies to see what has changed and how those changes may impact the future strategic and tactical plans of today's audit firms.

Table 1 - 2005 Study of CEO Ratings in Selection of Audit Firm

\begin{tabular}{|l|c|}
\hline Inc. 500 Selection Criteria & Rating \\
\hline Ethical reputation of CPA firm & 5.15 \\
\hline The CPA firm=s technical expertise & 5.06 \\
\hline The CPA firm=s industry expertise & 4.88 \\
\hline The personal relationships & 4.70 \\
\hline The CPA firm=s proposed fee & 4.44 \\
\hline The range of services available & 4.24 \\
\hline The formal oral presentation & 4.09 \\
\hline A recommendation from another organization & 3.91 \\
\hline The initial written proposal & 3.88 \\
\hline The size of the CPA firm & 3.85 \\
\hline The location of CPA firm & 3.56 \\
\hline CPA firm acquaintance with a key employee & 3.01 \\
\hline The availability of international services & 2.48 \\
\hline
\end{tabular}

(Scale: 6 = great importance; $0=$ no importance)

\section{FINDINGS}

In the 2005 study, "ethical reputation of CPA firm" was clearly the No. 1 factor according to responding CEOs.-with a 5.1 rating on a 6-point scale. On that same scale, the 2002 study revealed that CEOs rated "quality of 
CPA firm's technical expertise" as the most important factor-with a 4.9 rating. Our 2004 study confirmed the importance of technical expertise with a 5.0 rating, which placed it in the No.2 slot behind ethical reputation. CEOs carefully consider an audit firm's reputation before hiring an audit firm; thus, a reputation for integrity must be evident to the potential client. The publicity of the accounting_scandals over the past two-three years may well impact the consideration of the decision-makers when choosing a new audit firm.

The "technical expertise" high rating indicates that CEOs look for a high-quality service team assigned to their audit engagement. This factor topped the list in the 2002 study and was a close second in the 2005 study. Consequently, CPA firm personnel assigned to service the client must have the accounting skills to perform the required audit activities. Audit firms gain reputations for certain technical skills. CEOs and their audit selection team can examine the resumes of the potential audit personnel, looking for appropriate credentials, involvement in constant technical training, and prior audit experience.

In the 2002 study, the next highly rated factor (4.8) was "quality of industry experience" which was also No. 3 in the 2002 study (with a 4.5 rating). CEOs can make judgments as to the industry expertise of auditors who will be assigned to their firm by analyzing resumes for past audit experience in the client's industry, specific industry training completed, and involvement in appropriate industry associations. Accordingly, CEOs apparently look for a service team that not only has expertise in accounting and business operations but also has the knowledge and experience in the client's specific industry.

The fourth-highest factor in the 2005 study (4.7 rating) was the "personal relationships established between the CPA firm's key people and the client company's key decision-makers." This finding was also consistent with in the 2002 study; this factor was rated No. 2 with a 4.8. During the proposal process, an audit team's partners and managers would be wise to cultivate a strong professional relationship with the potential client firm's decision-makers by genuinely understanding and then addressing the client's specific needs.

Additional consistencies were found in examining the results of the 2005 and the 2002 studies. The controversial factor-"fees"-was consistently rated lower than the factors identified above: 4.4 rating in 2004 and 4.2 rating in 2002. Although an important factor, to be sure, ethical reputation, technical and industry expertise, and personal relationships consistently overpower the fee factor. Often, one audit firm accuses another audit firm of "lowballing" (significantly lowering the fees in order to win the audit). The firms that "lowball" mistakenly assume that by doing so the audit engagement is theirs.

Another comparison is worthy of comment: international resources. In both studies, this factor was rated at the bottom of the list-with ratings of 2.4 in 2004 and 2.3 in 2002. Large national audit firms often tout their international clout in their marketing literature and audit engagement proposals; yet, to small, successful firms, the 'international services' factor is not an issue of interest

Table 2 - 2002 Study of CEO Ratings in Selection of Audit Firm

\begin{tabular}{|l|c|}
\hline Inc. 500 Selection Criteria & Rating* \\
\hline The quality of the CPA firm's technical expertise & 4.92 \\
\hline $\begin{array}{l}\text { The personal relationships established between the CPA firm's key } \\
\text { people and the company's key decision makers }\end{array}$ & 4.81 \\
\hline The quality of the CPA firm's industry expertise & 4.51 \\
\hline The CPA firm's proposed fee & 4.28 \\
\hline The range of services available & 3.95 \\
\hline The quality of the formal oral presentation & 3.80 \\
\hline The location of CPA firm & 3.68 \\
\hline A recommendation from friend/contact in another organization & 3.68 \\
\hline The quality of the initial written proposal & 3.56 \\
\hline The size of the CPA firm & 3.50 \\
\hline $\begin{array}{l}\text { A CPA firm acquaintance with a key employee or member of the } \\
\text { board of directors }\end{array}$ & 3.14 \\
\hline The international services available & 2.38 \\
\hline
\end{tabular}




\section{IMPLICATIONS}

$(*$ Scale: $6=$ great importance; $0=$ no importance $)$

Results of both studies in 2002 and 2005 indicate that an audit firm must have "all the tools" to meet stringent criteria of CEOs of private small firms in their selection process. Uppermost must be an impeccable ethical reputation. Further to beat the competition for new clients, accounting practitioners must consider the client firm's needs very carefully. They must be able to communicate not only technical and industry qualifications but also to exhibit superb customer service.

Technical and industry expertise must receive constant attention, since a client firm demands such expertise. Besides providing training sessions for staff in the technical side of their business, managing partners need to spend significant resources on workshops which address ethical situations and moral values.

A company that asks for bids from audit firms looks for excellent oral and written communication skills of responding audit firms. During the proposal process, an audit firm must show a sincere effort to understand the client $=\mathrm{s}$ needs. Besides the interactions on the phone, through email, and in person, accounting professionals must expertly present their company $=\mathrm{s}$ image and skills in the written proposal and oral presentation to the clients decisionmakers. Thus, audit firms should spend quality time in hiring college graduates with excellent communication skills and training their staff continually in the art of customer service.

Audit firms need to be vigilant in maintaining the core value of integrity in all walks of their firm practices. In-house training should be programmed in such a way that periodically the audit firm provides their own ethics and customer service workshops for all staff members. Further, to be perceived as the audit firm of choice in both technical and industry experience, managing partners must constantly provide excellent training opportunities and the resources needed to involve their staff in industry associations. Learning to listen to a client's needs and responding to meet those needs cannot be overestimated. But, overriding and undergirding all of the factors must be the ethical conduct of all members of the audit firm. In the environment of today, an audit firm without this key ingredient will not be on the radar screen of a potential client who is selecting a new audit firm.

\section{REFERENCE}

1. Abbott, Lawrence J. and Parker, Susan, (2001), Audit Committees and Auditor Selection, Journal of Accountancy, vol. 191, Issue 6, 95.

2. Addams, H. Lon and Allred, Anthony, (2002), Auditing: Why the Fastest Growing Companies Hire and Fire Their Auditors, The CPA Journal, LXXII/No. 5 (May), 62-63.

3. Addams, H. Lon and Allred, Anthony, (2005), Ethical Reputation-Not Fees-Drive Auditor Selection at Inc. 500 Companies, Journal of Business and Economics Research, (March).

4. Addams, H. Lon and Davis, Brian, (1993), Managing Partners Share Marketing Insights Lowballing is Not Enough, Public Accounting Report, January 15 issue, 3.

5. Gregory, A. and Collier, P. (1996), Audit Fees and Auditor Change: An Investigation of the Persistence of Fee Reduction by Type of Change, Journal of Business Finance and Accounting, 23, 13-28.

6. Hermanson, R.H., Plunkett, L.M., and Turner, D.H., (1994), Study of the Importance of Certain Attributes to Client's Initial Selections of Audit Firms: A Longitudinal and Stratified Approach, Journal of Applied

Business Research; (Winter), 101-113.

7. Kwon, Soo Young, (1996), The Impact of Competition Within the Client's Industry on the Auditor Selection Decision, Auditing, vol. 15, Issue 1, 53-71.

8. Mano, Ronald M., Mouritsen, Matthew L., and Swearingen James G., (2003), Accounting Profession, Heal Thyself: A Matter of Survival, The CPA Journal, (August), 6-9.

9. Rummel, A., Davidson, S.M., and Acton, D. (1999), Getting New Clients and Keeping Old Clients, The CPA Journal, 69 (April), 56-57.

10. Stanny, E., Anderson, S., and Nowak, L., (2000), Contributing Factors in the Selection and Retention of Local Accounting Firms, The National Public Accountant, 45, issue 4, 19-21. 
11. Woo, E-Sah and Koh, Hian Chy, (2001), Factors Associated with Auditor Changes: A Singapore Study, Accounting \& Business Research, (Spring), vol. 31, Issue 2, 133-145. 